\section{Folic Acid in Pregnancy}

SIR,-In a leading article (24 December 1966, p. 1543) you state, "It is important to ensure that the dosage of folic acid given is correct ; on present findings it is $300 \mu \mathrm{g}$. daily." In the same article you state "Recent work by V. Herbert has shown that daily doses of folic acid of about $400 \mu \mathrm{g}$ may produce a response in patients whose megaloblastic anaemia is due to vitamin- $\mathrm{B}_{12}$ deficiency and it may therefore be undesirable to give such a dose for long."

In an article in "Current Practice" (18 February, p. 415) the dosage recommended is 100 to $200 \mu \mathrm{g}$. daily. The article gives various preparations and states, "The preparations contain more than adequate quantities of folate; this generous provision of folate is probably not of great consequence." I note that some of the preparations referred to in the article contain as much as $5 \mathrm{mg}$. of folic acid.

Thus the two articles differ markedly in regard to correct dosage of folic acid and possible risk from overdosage.-I am, etc.,

Manchester.

H. A. Koretz.

SIR,-There appears to be agreement that if folate supplement be given in pregnancy the quantity should be in $\mu \mathrm{g}$. and not $\mathrm{mg}$. amounts. Two criteria have been adopted in determining the amount of this supplementnamely, the dose that will prevent the appearance of a megaloblastic form of haemopoiesis in pregnancy, and, secondly, the dose that is required to maintain normal body stores of folate.

Your contributor (Today's Drugs, 18 February, p. 415) offered evidence that 100 $\mu \mathrm{g}$. folate daily was an adequate supplement in pregnancy. By contrast the valuable study reported by Willoughby and Jewell ${ }^{1}$ concluded that $300 \mu \mathrm{g}$. was the correct dose level, because they had encountered one example of megaloblastic anaemia in the puerperium among 88 patients receiving $100 \mu \mathrm{g}$. folate and none in the group receiving $300 \mu \mathrm{g}$. folate.

The criticism that can be levelled against the study reported by Willoughby and Jewell is that the diagnosis of megaloblastic anaemia does require the unequivocal demonstration of megaloblasts, and however useful some of the criteria used by these workers this was not one of them. Nor should a single example of megaloblastic anaemia even substantiated by marrow examination be sufficient evidence for or against any particular dose of folic acid, since failure by the patient to take tablets is a constant problem in this type of work. Indeed, Lowenstein and his colleagues ${ }^{2}$ were unable to eliminate megaloblastic anaemia in pregnancy with $500 \mu \mathrm{g}$. folate daily, probably for this reason.

On the other hand, the evidence that 100 $\mu \mathrm{g}$. folate on the average maintained unchanged the levels of folate in both red cells and serum throughout pregnancy suggested that this may prove a satisfactory dose to use in pregnancy.-I am, etc.,

St. Mary's Hospital,

I. ChanARIN.

London W.2.

\section{REFERENCES}

1 Willoughby, M. L. N., and Jewell, F. J., Brit. med. ${ }^{\prime}, 1966,2, \quad 468$

A. and Hsieh, Y. S. Proc., Cooper, B., Milad, Eur. Soc. Huemat. held Lisbon, 1963, Basle.

\section{The Thymic Vein}

SIR,-I am embarrassed by having become in your pages the apparent originator of an anatomical eponym-the "great vein of Keynes" (4 March, p. 566). I first described this vein in an article, "The Surgery of the Thymus Gland," where I remarked: "The venous drainage of the gland is concentrated in two large vessels running on the back of each lobe. These unite into one short trunk, usually of considerable size, which drains the blood into the front of the left innominate vein. This thymic vein is invariably present, and is a possible source of dangerous bleeding unless it is securely tied. It must therefore be identified with certainty every time." "This was illustrated with a drawing. "First descriptions" are notoriously liable to turn out later not to be first descriptions, and I made no claim to be the discoverer of this surgically important structure, though I was not able to find that it had in fact been described by any anatomist.

It was the mistaken kindness of my colleagues at New End Hospital that gave it the name of "the great vein of Keynes"merely a private joke when it so regularly appeared at each successive thymectomy. Dr. Kreel, in his most interesting article on the visualization of the thymus (18 February, $p$ 406), referred to the vein by this name, having heard it in common use while working out his technique at New End Hospital. Now Dr H. A. Dewar (4 March, p. 566) makes the facetious suggestion that the name should be amended to " the little vein of great Keynes." Hence my embarrassment, a private joke having become a public one. Most eponym are to be deprecated anyway. I should much prefer that the structure should in future be known simply as "the thymic vein."-I am, etc.,

$$
\begin{gathered}
\text { Brinkley, Cambs. } \quad \text { GeOfFrey Keynes. } \\
\text { Reference } \\
\text { ' Keynes, G., Brit. f. Surg., 1946, 33, } 201 .
\end{gathered}
$$

\section{Acute Gastric Ulceration Asssociated with Drug Therapy}

SIR,-Many side-effects have been reported with the use of ethacrynic acid, ${ }^{1-4}$ but the following case of acute ulceration of the stomach and duodenum with haemorrhagic rashes is of some interest, although the patient was being treated by a combination of drugs.

A man aged 65 years had chronic bronchitis and emphysema and had been admitted previously in congestive cardiac failure with atrial fibrillation. He had responded to treatment with digoxin, diuretics, effervescent potassium salt (which contains mainly potassium bicarbonate), and antibiotics. $\mathrm{He}$ never had potassium chloride. $\mathrm{He}$ had no previous history of dyspepsia.

On this admission on 30 May 1966 he was dyspnoeic, had peripheral cyanosis, was fibrillating, and had generalized oedema with bilateral basal crepitations. His right leg was more swollen than the left. The electrocardiogram showed no evidence of infarction or pulmonary embolism.

Treatment was started with oxygen, tetracycline, digoxin, frusemide (orally), mersalyl (alternate days), effervescent potassium salt, and Alevaire inhalations. Heparin (total three doses given) and phenindione were started on admission because he was thought to have deep-vein thrombosis on the right, but anticoagulant therapy was stopped three days after admission because his prothrombin time was 76 seconds (control 12 seconds). Frusemide was stopped on the ninth day as he had poor response to it and ethacrynic acid substituted $-50 \mathrm{mg}$. daily, later increased to $50 \mathrm{mg}$. b.d. Mersalyl was discontinued on the twenty-ninth day.

On 20 July, when he had been on ethacrynic acid only for about seven weeks, he developed purpuric and ecchymotic rashes on the thighs, legs, abdomen, sides of lower chest, etc., more anteriorly than posteriorly. Ethacrynic acid was stopped on $21 \mathrm{July}$, as this was thought to be the cause. Platelet count was 120,000 per cu. $\mathrm{mm}$. and W.B.C. was 9,600 per cu. mm. His condition gradually deteriorated. Three days later he complained of colicky, severe abdominal pain with tenderness maximal in the epigastric region and generalized guarding. Rectal examination showed a melaena stool. He passed a moderately severe melaena stool before he went into shock and died the same evening.

Post-mortem showed generalized peritonitis due to perforation of two recent gastric ulcers with multiple recent acute ulceration of varying sizes with haemorrhagic bases in the gastric mucosa (total eight gastric ulcers) and beyond the pylorus, four deeply scooped similar ulcers in the first part of the duodenum. The liver showed gross fatty degeneration. Other interesting post-mortem findings contributing to the cause of death were adherent pericarditis, with thrombosis of both iliac veins and a red infarct in the left lower lobe of lung.

I would like to thank Dr. A. Wingfield for giving me permission to publish this case.

-I am, etc.,

$$
\begin{aligned}
& \text { Dreadnought Seamen's } \\
& \text { Hospital, } \\
& \text { London S.E. } 10 .
\end{aligned}
$$

\section{REFERENCES}

1 Dollery, C. T., Practitioner, 1965, 194, 286. riedberg, C. K., Diseases of the Heart, 1966 3rd ed., London. Schröder, G., Sannerstedt R.. and Werkö, L. Acta med. scand 1964, 175, 781 . Daley, R., and Miller, H., Progress in Clinical
Medicine, 1966, Sth ed., London.

I should like to reply to some comments made in your correspondence columns of 11 February on my article on " Glycosuria of Pregnancy" (28 January, p. 205).

Dr. K. D. Salzmann (p. 360) professes greater faith in the weight of the baby than in any biochemical test on the mother in the detection of diabetes; I have every sympathy with this view so far as tests for urine glucose are concerned, since glycosuria in pregnancy has no correlation to diabetes at all.

With regard to blood-sugar estimations, I would agree with him that there is no justification for subjecting all multiparae to this test specifically, but where blood specimens are already being taken for other purposes this test could be added without inconvenience to the patient. It is true that few cases of diabetes will be found, but it is equally true that few cases of syphilis are discovered at antenatal clinics, yet the Kahn is an established routine test antenatally and accepted without question. Furthermore, in these days of diabetes detection drives why exclude the 